\title{
“A Relational Philosophy of Israel Education"
}

\begin{abstract}
Twenty-first-century Jewish life requires a new paradigm for Israel education that remains loyal to the past, but speaks to today and tomorrow. This chapter presents eight characteristics of a new approach denoted as "a relational philosophy of Israel education".
\end{abstract}

Keywords Cognitive emotions • Ethnic education • Jewish identity • Diverse narratives $\bullet$ The relational approach

\section{OUR TASK}

What a complicated life this little land has lived. It has been terra sancta to great religions. It has endured multiple conquerors and occupiers. It has been the object of holy memory and a vision of return. It is a modern state which is part of the family of nations. It is a source of conflicting aspirations and emotions. What a complicated life this little land lives.

This chapter focuses on the place of Israel in contemporary American Jewish education from the twentieth century until today. The diverse educational systems of American Jewry have taught about both the historical homeland and the newly created state established in 1948 (Chazan 2015).

This chapter is based on Chazan, B. (2017). A philosophy and Israel education: A relational approach. Palgrave Pivot.

(C) The Author(s) 2022

B. Chazan, Principles and Pedagogies in Jewish Education, https://doi.org/10.1007/978-3-030-83925-3_9 
While America's Jews focused on becoming Americans, they also wanted their young to learn about the nascent state.

The twenty-first century is a different place. Jews are fully at home in and constitute a robust part of American life. Twenty-first-century America is populated by a generation of post-ethnic multi-identified millennials (Hollinger 2000). The once pioneering State of Israel is now a powerful post-modern country located in a complex area of the world. These changes have significant implications for the relationship between American Jewry and Israel (Beinart 2012).

The prior Jewish agenda of community and continuity has been replaced by a millennial agenda of multiple identities, the search for meaning, and the creation of affiliations of shared meaning (Magid 2013). This situation calls for a new Israel educational paradigm that remains loyal to the past but is relevant to the realities of today and tomorrow. This reconceptualization reaffirms the centuries-long Jewish commitment to the concept of Israel. At the same time, it presents a new vision of Israel education as education for character and humanitas rather than ethnicity and particularism. The vision to be presented focuses on relating and relationship rather than "us versus them" (Buber 1934; Noddings 1992).

\section{EsTABLISHING A LANGUAGE}

I want to define certain key terms that that will be important for understanding of the relational philosophy of education to be presented in this chapter.

\section{Cognitive Emotions}

Typically, cognition and emotion have been regarded as polar opposites. Cognition is regarded as sober, calm, reflective, and detached, while emotion is regarded as passionate, turbulent, heartfelt, and engaged. Cognition is understood as a faculty of the mind with which we analyze things in a "sensible" way, whereas emotion is regarded as a faculty of the heart whereby we feel things with "great sensitivity". In a significant essay entitled, "In Praise of the Cognitive Emotions", the American analytic philosopher of education Israel Scheffler rejected the juxta-position of "the cognitive" and "the emotive" and instead described their inherent interaction. His purpose was to show that cognition incorporated emotional components derived from cognitive reflections and together they created 
"cognitive significance". This concept of cognitive emotions has important implications for our approach to Israel education.

\section{Homeland}

The word "homeland" is an important concept in the language of ethnicity and ethnic education and it is frequently used in Israel education. In its general usage, the term refers to a land (or an area), which is the place of origin of a people and its culture, as well as the locus of its history, language, customs, foods, and literary and artistic creations. In twentiethcentury America, the term "homeland" was associated with places from which millions of immigrants arrived. It was scrapbooks with photographs and memories; dinner tables of exotic and enticing cuisine; and the language one used when you didn't want the children to understand. America itself was not a "homeland"; it was the home of immigrants from diverse homelands. Homeland" only became an Americanized concept at the end of the twentieth century, especially after $9 / 11$, when it came to be associated with the security and preservation of the homeland of America. "Home" and "homeland" are important terms to clarify in the discussion of Israel education.

\section{Identity}

The word "identity" became popular in mid-twentieth-century America through the writings and teachings of Erik Erikson (Friedman 1999). In his early formulations, Erikson used the term "identity" to refer to one of eight stages in psychosocial development (Erikson 1980). According to this typology, there are a series of developmental stages over a lifetime, each of which involves a crisis or a crossroads whose resolution leads to the emergence of strengths important for a balanced and satisfying life. The crisis of the fifth stage ("adolescence") is "identity versus identity confusion", in which identity refers to a person's shaping a psychological sense of who she/he is. The optimal outcome of the stage of identity confusion is the virtue of fidelity. Thus, identity in its original usage was very much about one stage of development that has implications for other essential stages. Erikson most decidedly did not refer to identity as loyalty to a specific ideology or group attachment nor did he regard as a subject to be taught in classes as a goal of schooling. And that since the popular use of such terms as "Jewish identity" and "education for Jewish identity" is 
actually inaccurate and in fact the term "Jewish identification" which refers to degrees of Lincolnshire in lineage to the Jewish people might be a more precise concept.

\section{Israel}

The word "Israel" ( Yisrael in Hebrew) was first used in the Bible in Genesis 28:22 in presenting the narrative of Jacob wrestling with an angel and the subsequent changing of his name to "Israel". Eretz Yisrael-the Land of Israel-became the name of an area of the Middle East that in the Bible was called "Israel" and its inhabitants were called bnei Yisrael or Israelites. In the period of the Israelite monarchy (beginning approximately in the eleventh century BCE), the Northern Kingdom, composed of ten tribes, was denoted by the single word "Israel" while the two southern tribes were called "Judea" (Bright 1960). In post-Temple times (after $70 \mathrm{CE}$ ), the word "Israel" was used in diverse constellations such as Eretz Yisrael (the land), Am Yisrael (The Jewish people), Torat Yisrael (the Torah of Israel), and even Elohei Yisrael (The God of Israel). In later centuries, Jews in some Western and Central European countries were sometimes referred to as Israelite congregations. In 1948, when the new Jewish State was established, the name chosen for the country was The State of Israel (Frilling and Troen 1998). For thousands of years the word "Israel" has been connected in diverse ways to what we today call the Jewish people and one of the tasks of Israel education is to present discuss and explain the nature of these connections.

\section{Teaching Israel}

For most of the past century, the phrase used to describe the school-based educational activity related to Israel was "Teaching Israel" which denoted one of several subject-matter topics taught in Jewish supplementary and day schools. This subject-matter encompassed history of the biblical Land of Israel; the connection of the Jewish people with Israel over the ages and across continents in prayers, rituals, and customs; the emergence of the Zionist Movement in the late nineteenth and early twentieth centuries and the creation of the contemporary state of Israel in 1948. The topic was approached through diverse lenses - history, religion, customs, and sociology. At the beginning of the twenty-first-century, several Jewish 
educational voices replaced the "teaching Israel" terminology with the notion "Israel education", in order to broaden the venues of educating about Israel beyond schools as well as to highlight a learner-centered rather that subject-centered approach. ${ }^{1}$

\section{Narratives}

Narratives are ways of looking at the world-typically embedded in stories - to enable individuals or groups to make meaning out of the multifaceted realities of human life. Narratives are not fiction; they are philosophies. Various meanings of "Israel" are to be found in Jewish historical texts-biblical, rabbinic, modern, Zionist, contemporary statehood, and peoplehood-to help make sense of the concept in different eras. A variety of distinctive narratives of the meaning of "Israel" developed over time, reflecting a core commitment to the overall idea, expressed in diverse narratives. The Jews have not been the only groups with Israel narratives; there have been and there are diverse non-Jewish narrativesChristian, Muslim, and Palestinian-that reflect dramatically different understandings and interpretations of facts and events. Narratives will play an important role in the pedagogy of a "relational" Israel education.

\section{IsRaEl EducATION AS GoOd EducATION}

Israel education is obviously about Israel; it should be just as obvious that Israel education must first and foremost be good education. The idea of good education is rooted in several philosophical assumptions. The first assumption is that that we must learn how to be human and to coexist with others and that education plays an important role in that quest. (Oakeshott 1989). The second assumption is that human life is relational or dialogic, meaning that it is both shaped by and aimed at the ability of human beings to connect with each other in meaningful and humane ways (Buber 1934). The third assumption is that education is the process of developing the ability of human beings to both think and reflect on the core values of their lives and to come to admire and be committed to these core values as essential to their existence. The fourth assumption is that engagement with the other is central to the educative process (Dewey 1938; Rogers 1969). The fifth assumption is that education is not preparation for some far-off time called adulthood but rather is, as poignantly expressed by Polish Jewish educator Janusz Korczak, the growth, 
development, and reflection of the person in the here and now (Silverman 2017). I shall use the term "the relational approach" to describe this collection of assumptions and their implications for a twenty-first-century Israel education.

\section{Eight Principles of a Relational Approach TO ISRAEL EDUCATION}

Relational Israel education is rooted in eight educational principles that have significant implications for educational practice.

The first principle is that the individual- not Israel-is the center of Israel education. This principle indicates that the learner is the pivot or axis around which education revolves and for which education exists. This is not to say that the word "Israel" is insignificant, but it is not the starting point of Israel education-the learner is. While starting with Israel is tempting because it highlights an important topic, this direction usually leads to a preoccupation with Israel and neglect of the student. The person-centered assumption is rooted in the moral and epistemological belief that people of all ages can think and feel, and that understanding is a process that takes place at all stages of development. Therefore, the focus of education should be on the person's thinking, feeling, and doing. Jerome Bruner said that any child could be taught any subject at any age (Bruner 1960). Jean Piaget hypothesized that children are young scientists who actively try to explore the world and make sense of it (Piaget 1969). Lawrence Kohlberg suggested that children are moral philosophers who confront moral issues according to a series of well-defined developmental levels (Kohlberg 1980). Nel Noddings said that children can be taught to care (Noddings 1992). As we have seen, contemporary evolutionary psychologists and neuroscientists talk about "the moral sense", "the philosophical baby", "the ethical brain", and "the moral animal" (Gopnik 2009; Gazzaniga 2005; Wilson 1993; Wright 1994). If educators presume that the young can reflect and think, then they will likely discover that students can reflect and think. If educators presume that the young are furniture-less rooms, then they will continue to see their jobs as interior decorators. The relational approach to Israel education begins with the belief that the child is the starting point on the exciting journey of Israel education. 
The second principle of the relational approach is that the subject of Israel education is the individual's relationship with Israel. The word "subject" is generally used in education to refer to the content or body of knowledge to be taught. Typically, the "subject" of Israel education has been defined as the history of Israel, religious values related to Israel, and the story of contemporary State of Israel, all of which are regarded as contents to be transmitted to the young. Our second principle says that these topics are not the subject, but rather they all come to serve a more central preoccupation - the development of a personal and interpersonal relationship with Israel. This principle is based on the assumption that human life is interactional and relational, and thus dependent on connections with other ideas, values, beliefs, and people. This principle proposes that the intent of Israel education is about initiating, igniting, and nurturing a personal—and hopefully long-lasting — connection with Israel as it focuses on values, places, historical themes, the contemporary state, and people. The creation of the relationship, rather than the memorization of a definable quantity of material, is the subject of Israel education.

The third principle proposes that the aim of Israel education is the exploration of core ideas related to the concept of Israel as being part of the larger enterprise of developing and creating a personal relationship with Israel. It regards the explication and understanding of diverse Israel narratives as important for a person's journey toward the goal of making meaning out of Israel. This goal statement is rooted in an educational tradition defined alternatively as humanistic, liberal, progressive, or person-centered education (Dewey 1938; Oakeshott 1989; Rogers 1980). This principle implies that understanding Israel can lead to a sense of lineage with a past heritage, linkage with a contemporary like-minded group of people, and inner harmony with oneself. The phrase "meaning-making" is used to indicate that the pursuit of meaning is not frivolous, fleeting, or irrational; it is instead an activity in which one has to work seriously (Freud 1900). Meaning doesn't just happen; it involves the dynamics of searching, considering, and reflecting. It is work and takes time and effort. Moreover, meaning is not a subject to be taught in school, but a state of mind and heart that hopefully will emerge in the process of education.

The fourth principle is that along with understanding, meaning-making, and relating, the creation of an Israel culture is a primary pedagogic focus of Israel education. The culturalist theory is a perspective which emphasizes the significant role in education of environment and context, such as language, aesthetics, arts, food, and customs (Bruner 1996; Cole 1996, 
Vygotsky 1978; Cole 1996). The cultures we live in are profound factors in shaping mind and self:

Learning and thinking are always situated in a cultural setting and always dependent on the utilization of cultural resources ... Culturalism takes as its first premise that education is not an island, but part of the continent of culture.

This means that Israel education includes the shaping of an immersive environment encompassing any and every component that constitutes the venue in which people learn, whether it be the architecture, peer culture, hidden curriculum, teacher's personality or even the weather. The architectonics of Israel education go beyond the normal course of study and include a much broader palate of educational opportunity. This means that the totality of educational institutions can be harnessed for Israel education.

The fifth principle of relational Israel education is that the rich corpus of diverse Israel narratives which form part of the Jewish heritage should be encountered and introduced within the context of Israel education. These narratives reflect diverse ways of looking at the world within the context of the Jewish experience. The tasks of Israel education in this instance are fourfold. (1) To enable the learner to understand that the Jewish people have retained an overall commitment to the Land of Israel as one of its core values. (2) To enable the learner to discover that diverse meanings and understandings of Israel have been part of Jewish life over the ages. (3) To facilitate an appreciation in the student that the multiplicity of Israel narratives reflects a tradition which invites reflection, interpretation, and an understanding of the changing environments in which Jews have lived. The fact that contemporary Israel is a particularly charged topic does not mean that teachers or students must leave their cognitive skill sets in the locker room when dealing with this topic. They must approach it with the same cognition and passion they would employ when confronted with any serious question. (4) To assist the young in acquiring tools that will enable them, at some point, to carve out their own personal Israel narrative. Ultimately, Israel education is about internalizing the virtues of intellectual honesty, curiosity, integrity, and commitment, all of which are critical for making us human.

The sixth principle is that good Israel education happens when there is connectivity between what we have previously described as Aims, Goals, 
Objectives, (AGO). Such connectivity or consilience is reflected in the Athenian Greek notion of paideia or the Jewish notion of Talmud Torah, wherein a core educational vision shapes the totality of society and life (Jaeger 1943). The more an educational system can coordinate its vision, educational theory, and practice, the greater the possibilities of impact. Developing a practice is not a matter of seeking "good programs that work". The integration of the diverse components of the educative process is a desideratum of Israel education. Such an approach aspires to create an educational symphony which both artfully and intelligently creates music that resonates with the hearts and minds of the young.

The seventh principle requires pedagogues who understand the overall vision, have the ability to make Israel narratives accessible to the student, can shape cultures, and have the courage to be accessible models and to teach "from within" (Palmer 1998). Understanding the vision implies a deep familiarity with the narratives of Israel that are the heritage of the Jewish people. Having the ability to make these narratives accessible encompasses skills in relationship-building, questioning, and group dynamics. Shaping cultures means creating settings that teach by immersing the student in an environment which "breathes" Israel. "Teaching from within" refers to the willingness of pedagogues to reach into themselves and model their "Israel relationship" (and its complexities) with love and passion. Those best suited to engage in Israel education are people who co-opt their personal passion and questions in order to model a commitment that is human but not uncritical.

The eighth principle of a relational Israel education is the recognition of the power and limits of education. Emile Durkheim saw education as allpowerful; Sigmund Freud spoke of the near-futility of teaching (Freud 1979) The truth lies somewhere between Durkheim and Freud: Education - and Israel education - can make a difference and may well contribute to a meaningful relationship with Israel. At the same time, we should not forget the plethora of other forces-genetics, family, media, cyberspace, life's twists and turns - which play such a significant role in shaping who we become. Israel education is not the answer, the solution or magic bullet, but Israel educators are entrusted with the opportunity to make a difference. Israel education may feel like a Sisyphean task, yet, as educators, we still try to roll the stone up the mountain. And there are times when we actually succeed. 


\section{CODA}

So what is Israel education according to the relational approach? It is the exhilarating yet humbling mission of educating people to think, feel, and integrate Israel into their overall character as Jews and as human beings. It is about the attempt to help young Jews study their particular culture in order to find meaning in a place, an idea, a people, and a value that has been dear to their tradition for millennia. Israel education is about helping people seek answers to life's most basic questions through the portal of their particular tradition.

\section{Note}

1. The book, entitled, The Aleph Bet of Israel Education, 2nd Edition 2015 presents core principles and practices of a twenty-first-century theory and practice Israel education. (Lanski, editor, 2015).

\section{BiBLIOGRAPHY}

Aristotle, \& Ross W. D. 1966. The Works of Aristotle. (Oxford University Press).

Beinart, P. 2012. The Crisis of Zionism. (Times Books).

Bright, J. 1981, 1960. A History of Israel.

Bruner, J. 1960. The Process of Education. (Harvard University Press).

Bruner, J. 1996. The Culture of Education. (Harvard University Press).

Buber, M. 1934. I and Thou (2nd ed). (Charles Scribner's Sons).

Chazan, B. 2015. "A Linguistic Analysis of the Role of Israel in American Jewish Schooling" in The Journal of Jewish Education. 81, 5, 85-92.

Cole, M. 1996. Cultural Psychology: A Once and Future Discipline. (Belknap of Harvard University Press).

Dewey, John 1938. Experience and Education. (Macmillan).

Erikson, E. 1980. Identity and the Life Cycle. (Norton).

Freud, S. 1900. The Interpretation of Dreams. (Basic Books).

Freud, S. 1979. Civilization and Its Discontents. (Hogarth Press).

Friedman, L. 1999. Identity's Architect: A Biography of Erik H. Erikson. (New York: Scribner's).

Frilling, T. and Troen, I. 1998. Proclaiming Independence: Five Days in May from Ben-Gurion's Diary. Israel Studies, 3(1), 170-194.

Gazzaniga, M. S. 2005. The Ethical Brain. (Dana Press).

Gopnik, A. 2009. The Philosophical Baby: What Children's Minds Tell Us About

Truth, Love, and the Meaning of life. (Farrar, Straus and Giroux).

Hollinger, D. 2000. Post Ethnic America: Beyond Multiculturalism. (Basic Books). 
Jaeger, Werner. 1943. Paideia: The Ideals of Greek Culture. (Oxford University Press).

Kohlberg, Lawrence. 1980. The Philosophy of Moral Development. (Harper and Row).

Lanski, Anne, editor. 2015. The Aleph Bet of Israel Education. (The I Center for Israel Education).

Magid, Shaul. 2013. American Post Judaism: Identity and Renewal in a Post Ethnic Society. (Indiana University Press).

Noddings, Nel. 1992. The Challenge to Care in Schools: An Alternative Approach to Education. (New York: Teachers College Press).

Oakeshott, M. 1989. The Voice of Liberal Learning. (Yale University Press).

Palmer, P. J. 1998. The Courage to Teach: Exploring the Inner Landscape of a Teacher's Life. (Jossey-Bass).

Piaget, J. 1969. Science of Education and the Psychology of the Child. (Penguin Books). Rogers, C. R. 1969. Freedom to Learn: A View of What Education Might Become. (C.E. Merrill Publishing company).

Rogers, C. R. 1980. Freedom to Learn. C. E. (Merrill Publishing Company.) 1986. Scheffler, I. 1991. In Praise of the Cognitive Emotions and Other Essays in the Philosophy of Education. (Routledge).

Vygotsky, L. S. 1978. Mind in Society. The Development of Higher Psychological Processes. (Harvard University Press.) 1980.

Vygotsky, Lev. 1994. The Vygotsky Reader. (Wiley-Blackwell).

Wilson, J. Q. 1993. The Moral Sense. (Free Press).

Wright, R. 1994. The Moral Animal. (Vintage).

Open Access This chapter is licensed under the terms of the Creative Commons Attribution 4.0 International License (http://creativecommons.org/licenses/ by $/ 4.0 /$ ), which permits use, sharing, adaptation, distribution and reproduction in any medium or format, as long as you give appropriate credit to the original author(s) and the source, provide a link to the Creative Commons licence and indicate if changes were made.

The images or other third party material in this chapter are included in the chapter's Creative Commons licence, unless indicated otherwise in a credit line to the material. If material is not included in the chapter's Creative Commons licence and your intended use is not permitted by statutory regulation or exceeds the permitted use, you will need to obtain permission directly from the copyright holder.

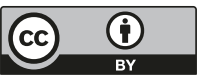

